\title{
To Pay Attention to Investment in Human Capital and to Revitalize Old Industrial Bases in Northeast China
}

\author{
Dianwei Qi \\ Post-doctoral Research Center in Business Management, Jilin University \\ $\&$ \\ Changchun University of Science and Technology \\ Changchun 130022, China \\ E-mail: qidianwei1111@126.com \\ $\mathrm{Li} \mathrm{Li}$ \\ Changchun University of Science and Technology \\ Changchun 130022, China
}

\begin{abstract}
In 2003, the Central Committee of the Communist Party of China made an importance decision to revitalize old industrial bases in Northeast China. quite a large number of experts and academics have provided specific resolutions to how to revitalize old industrial bases in Northeast China. However, there are still some people who hold the idea of waiting, depending and asking, and they believe that only if the country provides loan, policy and project, can old industrial bases in Northeast China be revitalized. To revitalize old industrial bases in Northeast China is a long term process, so offer of loan, policy and project by the country can only resolve demand for momentary use. The top priority is still to integrate human capital and strengthen vigor of investment in human capital. In view of the above situation, this article points out significance of investment in human capital compared with investment in material capital and mentions that in the process of revitalizing old industrial bases in Northeast China, in addition to offer of loan and project by the country, we should change our mind and make use of our intelligence and wisdom to strengthen vigor of investment in human capital and to revitalize old industrial bases in Northeast China.
\end{abstract}

Keywords: Human capital, Investment in human capital, Revitalize, Old industrial bases in Northeast China

Human capital theory was proposed by Schurz in 50 s and 60 s in the Twentieth Century. After its development, evolvement and dissemination for over half a century, human capital theory has so far become one of the theories in economics that are widely applied. The concept of human capital has, so far, not had a unified concept, and it usually refers to the sum of value of knowledge, skill and physical power (health condition), and is formed by means of investment in such aspects as hygiene and education. In earlier economic development theories, material capital was regarded as the key element of economic development. However, since 1960s, more and more economists have gradually realized the important effect of human capital on economic development. There are even some economists who take human capital as the decisive element of economic development. It is estimated, in the contemporary developed economic system, when investment in material capital is added by $\$ 1$, the output increases by $\$ 1-3$, whereas when investment in human capital is added by $\$ 1$, the output increases by \$3-10. As one of the key elements for economic development, human capital has significant effect upon diminishing gap between backward areas and development areas, play of regional comparative advantage, formation of rational regional division pattern and sustainable development.

According to Schurz, for economically backward areas to enter the economic development stage, the most important factor was not material capital, but human capital. Human capital can not only improve the productivity of laborers themselves, but also its external effect may spread to other laborers and can transfer from old products to new products. Thus, it will improve productivity of all production elements and furthermore, will realize increasing return to scale. Boom of west Europe and Japan after the Second World War exactly proves the significance of human capital to sustainable development of a country. Although Japan and west Europe were lacking in resources, they were rapidly developed after the War. This is enough to prove the 
significance of human capital investment to sustainable development of a country and a region. Northeast China may borrow successful experiences of Japan and South Korea in terms of investment in human capital investment to realize great-leap-forward development.

Investment in human capital should coincide with investment in material capital. Excessive investment in material capital and ignorance of investment in human capital may result in idelness of machines and equipment. This can not only not stimulate economic growth, but may, on the contrary, lead to waste. Increased human capital stock and improved quality may improve quality of production elements, because human capital with high quality may replace natural resources and alleviate shortage of resources. Human capital accumulation may not only more effectively use such material capital as machines and equipment to enhance use efficiency of material capital by improving its skills, but can also make full use of or replace rare material capital to add to the total output. To pay attention to investment in human capital seems extremely urgent for old industrial bases in Northeast China with shortage in material capital and gradually reduced and even exhausted resources.

Thus, in order to revitalize old industrial bases in Northeast China, we have to break away from the inertial thinking of planned economy that strives for policy and for investment. Both the government and the society should attach great importance to investment in human capital and fully excavate and employ talents to revitalize old industrial bases in Northeast China.

\section{Relationship between human capital and economic growth}

Human capital theory was proposed by Schurz in 50s and 60s in the Twentieth Century. After its development, evolvement and dissemination for over half a century, human capital theory has so far become one of the theories in economics that are widely applied.

The concept of human capital has, so far, not had a unified concept, and it usually refers to the sum of value of knowledge, skill and physical power (health condition), and is formed by means of investment in such aspects as hygiene and education. In earlier economic development theories, material capital was regarded as the key element of economic development. However, since 1960s, more and more economists have gradually realized the important effect of human capital on economic development. There are even some economists who take human capital as the decisive element of economic development. As one of the key elements for economic development, human capital has significant effect upon diminishing gap between backward areas and development areas, play of regional comparative advantage, formation of rational regional division pattern and sustainable development. After an empirical analysis of the economic development rule of USA in 1929 to 1957, Schurz discovered that the wealth of contemporary high income countries mainly came from human capital.

Since 90s of the Twentieth Century, many economists have discovered through experimental research the contribution of human capital to economic growth and the scope of the contribution. Rate of contribution by expenditure of public education to growth in output is great and the rate of return of investment in human capital is higher than that in material capital. It is estimated, in the contemporary developed economic system, when investment in material capital is added by $\$ 1$, the output increases by $\$ 1-3$, whereas when investment in human capital is added by $\$ 1$, the output increases by $\$ 3-10$. In order to revitalize old industrial bases in Northeast China, we should attach great importance to investment in human capital and regard full use of the abundant human capital as the entry point to realize "advantage of backwardness". Output elasticity of elementary education is generally larger than that of secondary education. Human capital is merely a necessary condition for economic growth, but not a sufficient condition. Social and economic development can not purely depend on investment in human capital, but requires the mechanism and policy coordinated with it. And human capital needs to have production function in the two aspects of element and efficiency. Element means that human capital is an indispensable prerequisite or investment element of production process, whereas efficiency means that human capital is the key factor to improve production efficiency, with the precondition that increase in human capital may improve the production efficiency of human capital itself and production efficiency of other production elements. As one of production elements, on one hand, human capital makes a direct contribution to economic growth, and, on the other hand, boosts economic growth by means of stimulating scientific and technical progress, which is the "primary productive force" of social and economic development. Human capital has knowledge effect, including demand effect, income effect and substitution effect of knowledge progress. Knowledge income effect of human capital means that those who are educated and trained and have more knowledge and capacity will have higher productivity, because they have higher judgment ability and are able to grasp opportunities to make an investment and make a profit at any time. The knowledge substitution effect of human captain means that one can increase resources by progress of knowledge. Compared with all other elements, the supplement and substitution effect of human capital has become more and more important. This 
can enable the substitution effect of knowledge to overcome deficiency of natural resources, material capital and "original labor force" in economic development and retain sustainable development of economy. The substitution effect of economy is also manifested in the fact that, human capital can produce incremental profits and eliminate unfavorable influences of progressive decrease of such marginal income as material capital upon long term growth of economy.

\section{Significance of investment in human capital to revitalize old industrial bases in Northeast China}

Economy in Northeast China has had an impressive achievements and brilliance. Since the founding of China until 1978, the GDP per capita in the three provinces in Northeast China ranked only second to the three municipalities of Beijing, Tianjin and Shanghai and had been in a leading position in the entire country. However, from 1994 to 2004, the three provinces of Liaoning, Jilin and Heilongjiang ranked respectively $8^{\text {th }}, 14^{\text {th }}$ and $10^{\text {th }}$ from the original position of $1^{\text {st }}, 7^{\text {th }}$ and $4^{\text {th }}$ in terms of GDP per capita. In order to accelerate development of Northeast China and even the whole country, the Central Committee of CPC made a significant decision in 2003 to revitalize old industrial bases in Northeast China and took this decision together with the plan of western development as the two wheels of modernization construction and interaction between east China and west China. in order for economically backward areas to enter the economic development stage, the most important factor is not material capital, but human capital. Human capital can not only improve the productivity of laborers themselves, but also its external effect may spread to other laborers and can transfer from old products to new products. Thus, it will improve productivity of all production elements and furthermore, will realize increasing return to scale.

Boom of west Europe and Japan after the Second World War exactly proves the significance of human capital to sustainable development of a country. Although Japan and west Europe were lacking in resources, they were rapidly developed after the War. This is enough to prove the significance of human capital investment to sustainable development of a country and a region. Old industrial bases in Northeast China may borrow successful experiences of Japan and South Korea in terms of investment in human capital investment to realize great-leap-forward development. According to Schurz, the fundamental reason for poverty of a nation or a region is not that they are extremely lacking in capital. And the viewpoint that the key to rapidly obtain economic growth is to add capital is not complete. Newly provided foreign capital for these poor countries or regions are usually used for construction and equipment and sometimes are used to purchase inventory, but are usually not used to add to investment in human capital. Capacity of human being does not keep pace with material capital. The ability of these countries to absorb material capital added is poor, so investment in human capital is more important for them.

In the process of revitalizing old industrial bases in Northeast China, quite a large number of experts and academics have offered specific resolutions. Different people have different views. However, there are still some people who hold the idea of waiting, depending and asking, and they believe that only if the country provides loan, policy and project, can old industrial bases in Northeast China be revitalized. This wrong idea may obstruct revitalization of old industrial bases in Northeast China. we should set up correct concept of development. In addition to offer of loan and project by the country, we should change our mind and make use of our intelligence and wisdom to strengthen vigor of investment in human capital and to revitalize old industrial bases in Northeast China.

Human capital and material capital may replace each other to a certain extent. A certain amount of material capital and a certain amount of human capital can produce a certain amount of income. Generally, a small amount of material capital and a large amount of human capital can produce similar income or a large amount of material capital and a small amount of human capital can produce similar national income. Excessive investment in material capital and ignorance of investment in human capital may result in idelness of machines and equipment. This can not only not stimulate economic growth, but may, on the contrary, lead to waste. China has profound lessons. Thus, in the process of revitalizing old industrial bases in Northeast China, we should absorb the lessons. Increased human capital stock and improved quality may improve quality of production elements, because human capital with high quality may replace natural resources and alleviate shortage of resources. Human capital accumulation may not only more effectively use such material capital as machines and equipment to enhance use efficiency of material capital by improving its skills, but can also make full use of or replace rare material capital to add to the total output. To pay attention to investment in human capital seems extremely urgent for old industrial bases in Northeast China with shortage in material capital and gradually reduced and even exhausted resources.

Although there are a lot of research institutes and colleges and universities in old industrial bases in Northeast 
China, the inventory of overall human capital is not enough, with the phenomenon of imbalance. Talent structure and economic structure do not match each other. The most important reason is that education and training are disconnected with economic development in addition to flow out of professionals whose skills are in short supply. Professional pattern of such educational institutions as vocational schools, financial schools, agricultural schools and technical secondary schools do not suit with demand of local economic and social development on talents. On one hand, source of students in these schools is seriously deficient, and on the other hand, talents that are in short supply in enterprises have no place to be trained. In the process of economic development, we have paid too much attention to investment in human capital of entrepreneurs and high-tech talents, but have ignored investment in the extensive workers and farmers.

Thus, in order to revitalize old industrial bases in Northeast China, we have to break away from the inertial thinking of planned economy that strives for policy and for investment. Both the government and the society should attach great importance to investment in human capital and fully excavate and employ talents to revitalize old industrial bases in Northeast China.

\section{To pay attention to investment in human capital and to revitalize old industrial bases in Northeast China}

The most outstanding issue in old industrial bases in Northeast China is the issue of city resource exhausted city transition. Old industrial bases in Northeast China were ever resourceful areas and contained coal, wood and oil. Yet, as a result of several reasons, resources in these areas became gradually exhausted. The discussion group of "Economic Structure Transition of the Resource-based Cities" of National Development and Reform Committee (NDRC) confirmed 60 typical regions in the 118 resource-based cities, including the following 19 in old industrial bases in Northeast China: Fushun, Fuxin, Tiefa, Beipiao, Liaoyuan, Jixi, Hegang, Shuangyashan, Qitaihe, Benxi, Daqing, Panjin, Dunhua, Hunchun, Songyuan, Linjiang, Helong, Yichun and Tieli. Fuxin is one of the earliest coal and electricity production bases in New China and has made significant contributions to economic establishment of the country. During the period of "the first Five-Year Plan", among the 156 national key projects that laid the national industrial foundation, four energy projects were arranged in Fuxin. From the founding of New China until the end of 2000, Fuxin had altogether generated 150 billion Kilowatt of electricity and had produced 0.53 billion tons of raw coal, and if the raw coal were carried by 60 tons of trucks, these trucks might orbit the planet earth for 4.3 cycles. However, at present, after fifty years of brilliance, this famous coal city is finally troubled by coal. Its coal resources are exhausted, with 156 thousand laid-off workers and 300 thousand families living with difficulty. Thus, its economy has slowed down year by year.

As the largest oil production base and the most important petrochemical industrial base in the country, Daqing has already produced 1.624 billion tons of crude oil since its development and establishment for over 40 years, accounting for $44.6 \%$ of the total amount of on-shore oil all over the country in the corresponding period. However, after high and stable yield of Daqing Oilfield for 24 years, its exploitable reserve was far away from satisfying the long term demand of an annual output of 50 million tons. Within the later several years, output of Daqing Oilfield will decrease progressively with a speed of about an output of 1.5 million tons each year. If the oilfield reduces its output year by year, then it may be difficult for growth in local economy to make up for influences caused by reduced production of oil. Local economy of Daqing only has a scale of about 10 billion Yuan, so even if it keeps a growth rate of above $30 \%$, it can only add an output value of 3 billion Yuan each year. Ecological environment problem is also prominent in Daqing. At present, the percentage of forest cover in Daqing is merely $9 \%, 8.05$ percentage lower than the average national level. The area of grass-land deterioration, salinization and desertification has already occupied $84 \%$ of the total area, which does serious harm to ecological balance. Daqing has drought nine years out of ten, and it is often sand wind in Spring and Autumn. Even water resource is in an emergency. Demand on industrial and agricultural production and water consumption each year in the whole city is 2.6 billion tons, but only 2.2 billion tongs of water is available. Underground water resource is seriously overlifted, leading to underground funnel within a large sphere.

Academician Xu Shoubo has ever pointed out, whatever cities are troubled with the issue of transition. It will not last long to rely on resources and it will be full of risks to rely on capital. And the longest and most secure way is to depend on science and technology and on talents.

Old industrial bases in Northeast China and even all other regions in China attached great importance to pursuit of development speed in the past, but ignored synchronous improvement of quality and profit; emphasized strength and speed of reform, but neglected overall consideration of interests of all parties; paid attention to pushing forward economic development, but ignored coordination and follow-up of social career, urban construction and environmental protection. In order to resolve fundamentally all the above issues, we have to 
persist in the Scientific Outlook on Development to lead the overall situation of revitalization, come to full realization of the important role of human capital investment in economic development, insist on developing higher education, cultivate high-level talents and pay attention to training on laid-off workers and farmers. The society should also abandon the idea that entrepreneurs and high and new technical talents are human capital and should not ignore improving investment in human capital of the extensive laid-off workers and farmers. However, conservation and utilization of resources and sustainable development of rural areas and even urban development all fall over the extensive farmers. Thus, the whole society should go into action to integrate human resources, improve investment in human capital, revitalize old industrial bases in Northeast China and fulfill sustainable development of old industrial bases in Northeast China.

3.1 To change traditional concept, come to realize importance of investment in human capital and set up the investment concept, property right concept, market concept, profit concept and strategic concept of human capital

3.2 To carry out loan strategy of human capital for later-developing countries and to obtain later-developing profits in investment in and transfer of human capital

Offer of preferential terms and absorption of talents in all fields can save actual investment cost and produce progressive human capital dissemination and driving effect.

3.3 To integrate educational resources, reinforce educational investment and optimize initial stock of human capital

Education is the approach and means to cultivate and accumulate human capital, so we have to attach great importance to investment at all levels, including higher education, vocational education, nine-year compulsory education and especially nine-year compulsory education and training of adults in remote and impoverished mountainous areas and prevent the phenomenon of excessive and deficient investment in human capital. We should also give full play to the role of the government as the subject in investment in human capital to stimulate investment in social human capital. In case that the government investment was insufficient, we should actively and enthusiastically absorb nongovernmental capital investment. Enterprises and all kinds of relevant social organizations constitute an important occasion to employ human capital. On the contrary, the extensive farmers neither have participated in any training, nor have held any position in an enterprise, so the issue of investment in human capital of such a group requires special research.

3.4 To integrate human resources and to pay attention to integration of senior artisans and common artisans in enterprises in old industrial bases in Northeast China

Actually, the total amount of talents in Northeast China area is relatively large, with concentrative colleges and universities, technical secondary schools and research institutes and extremely abundant scientific talents resources. Among laid-off employees in some enterprises, quite a large number of them are experts within their own field. These people can turn to wealth from burden, so we should integrate these people in a rational way, which can resolve the phenomenon of shortage of artisans in some enterprises.

\section{References}

Chen, Biqing. (2003). On Developmental Strategy for Human Capital in Western Development. Journal of Southwest University for Nationalities, 8.

Liu, Guizhi. (2004). Effect of Human Capital in Evolvement of Industrial Structure in Northeast China. Inquiry into Economic Issues, 6.

Liu, Jiaqiang. (2004). New Theory of the Economy of Population. Sichuan: South-West University of Finance \& Economics Press.

Shi, Caiying. (2003). To Strengthen Investment in Human Capital and to Realize Sustainable Development of Economy. Shanxi Statistics, 1.

Xie, Yi. (2001). Formation and Development of the Theory of Human Capital. Human Resource Development of China, 2. 